\title{
Elicitation of peroxidase activity in genetically transformed root cultures of Beta vulgaris L.
}

\author{
Thimmaraju Rudrappa \\ Plant Cell Biotechnology Department \\ Central Food Technological Research Institute \\ Mysore 570 020, India \\ Tel: 918212516502 \\ Fax: 918212517233 \\ E-mail: rajurt@UDel.Edu

\section{Bhagyalakshmi Neelwarne*} \\ Plant Cell Biotechnology Department \\ Central Food Technological Research Institute \\ Mysore 570 020, India \\ Tel: 918212516502 \\ Fax: 918212517233 \\ E-mail: blakshmi_1999@yahoo.com \\ Venkatachalam Lakshmanan \\ Plant Cell Biotechnology Department \\ Central Food Technological Research Institute \\ Mysore 570 020, India \\ Tel: 918212516502 \\ Fax: 918212517233 \\ E-mail: genevenki@yahoo.com
}

\section{Sreedhar Reddampalli Venkataramareddy \\ Plant Cell Biotechnology Department \\ Central Food Technological Research Institute \\ Mysore 570 020, India \\ Tel: 918212516502 \\ Fax: 918212517233 \\ E-mail: rvsree@rediffmail.com}

\section{Ravishankar Gokare Aswathanarayana}

Plant Cell Biotechnology Department

Central Food Technological Research Institute

Mysore 570 020, India

Tel: 918212516502

Fax: 918212517233

E-mail: pcbt@cftri.res.in

Financial support: Senior and Junior Research Fellowship from the Council of Scientific and Industrial Research, India.

Keywords: Aspergillus, calcium, culture filtrate, dried cell powder, elicitor, glutathione, methyljasmonate, Rhizophus, thidiazuron.

Abbreviations: $\quad$ CF: culture filtrate

DCP: dry cell powder

GSH: glutathione

Mej: methyl jasmonate

MS: Murashige and Skoog

PDA: potato dextrose agar

POD: peroxidase

PP: phenylpropanoid

TDZ: thidiazuron

Genetically transformed roots of red beet produce copious levels of peroxidase (POD) - a multifunctional enzyme with a number of commercial applications. In an effort to elicit the POD activity, the cultures were

*Corresponding author 
treated with biotic elicitors such as dry cell powders of microbial cultures $(0.1-0.5 \% \mathrm{w} / \mathrm{v})$ and the respective culture filtrates $(1-5 \% \mathrm{v} / \mathrm{v})$. Similarly, abiotic elicitors, particularly metal ions (2-8 folds of that present in the nutrient medium), the plant hormone Thidiazuron (at 0.25-1 ppm) and other bio-molecules such as Glutathione (at 0.5-10 mM) and Methyl jasmonate (at 20-100 $\mu \mathrm{M}$ ) were used. It was observed that dry cell powder of Candida versatilis significantly elicited the enzyme activity (3.52-fold higher than the control) followed by glutathione (3.44-fold) and Rhizophus oligosporus (3.09-fold). Among abiotic elicitors, thidiazuron, $\mathrm{Mg}$ and $\mathrm{Ca}$ salts elicited 2.49, 3.03 and 2.8 fold activities respectively. While most of the biotic elicitors were effective when added on $15^{\text {th }}$ day of culture, the abiotic elicitors were effective when added on $20^{\text {th }}$ day. Combination of highly effective elicitors indicated that glutathione $(1 \mathrm{mM})$ and dry cell powder of $R$. oligosporus caused a 4-fold enhancement in enzyme activity, accounting for $10.9 \times 10^{6} \mathrm{U} \mathrm{L}^{-1}$. The present study is the first report on red beet hairy roots where a large number of elicitors have been systematically screened and their probable involvements in eliciting POD activities have been discussed.

Plants are a rich source of various phytochemicals, proteins, enzymes and other secondary products of immense biotechnological applications. The secondary products and the respective enzymes, particularly those of phenylpropanoid pathway are significantly enhanced under the influence of elicitors. Peroxidase (POD) is one such enzyme associated with the plant defense pathway and is elicited when challenged with elicitors (Gómez-Vásquez et al. 2004; Perera and Jones, 2004). Since this enzyme also has various commercial applications, the present communication is focused on developing a strategy for eliciting POD enzyme that is associated with secondary metabolites of defence functions.

Peroxidase (E.C. 1.11.1.7) can oxidise various substrates due to its ability to perform a number of different types of reactions, such as peroxidative oxidation or oxidative and catalytic hydroxylation (Uyama and Kobayashi, 2003; Veitch, 2004). These reactions indicate a wide array of applications for peroxidases as a component of reagents for clinical diagnosis and various laboratory experiments. Although a large number of commercial applications of POD are possible, the high cost of presently available horseradish POD hinders such applications, which indicates the need for alternative sources of POD. We reported high levels of POD activity in cultured hairy roots of red beet (Thimmaraju et al. 2005) and the present study reports screening of a number of biotic and abiotic elicitors and the interaction of two complex elicitors leading to overexpression of POD activity.

\section{MATERIALS AND METHODS}

A hairy root clone, established by infecting the cotyledonary leaf explants obtained from aseptic seedlings of the red beet variety "Ruby Queen" with $A$. rhizogenes strain LMG-150, was used throughout the present study. Induction of hairy roots and their maintenance conditions have been explained in an earlier communication (Thimmaraju et al. 2003). For testing growth performance, approximately $50 \mathrm{mg}$ of root tips from hairy root clones were sub-cultured in $50 \mathrm{ml}$ Erlenmeyer's flasks containing $15 \mathrm{ml}$ of MS basal liquid medium (Murashige and Skoog, 1962 ) with $3 \%$ sucrose and grown on a rotary shaker as described previously. The biomass accumulation and POD level were monitored at 5 day intervals. Fresh weight increase was recorded after removal of the spent medium by suction while the biomass was retained in a Buchner funnel.

\section{Biotic elicitors}

Crude elicitors. Based on earlier reports and the availability of cultures, CF and DCP of various fungi, yeast and bacteria were used. The fungi used were $A$. parasiticus, Aspergillus niger, Penicillium notatum, and Rhizophus oligosporus. The Yeast species used was Candida versatilis. Among the bacteria Lactobacillus helveticus was used. Food Microbiology Department CFTRI, Mysore, kindly supplied all the microbial cultures.

\section{Maintenance of microbial cultures}

Fungi and yeast. The fungal and yeast cultures were maintained as slants in potato dextrose agar (PDA). This medium contained $20 \mathrm{~g}$ of dextrose and $\mathrm{pH}$ adjusted to 5.5 with $10 \%$ tartaric acid, and $20 \mathrm{~g}$ of agar. The final volume was made up to one litre using distilled water and the autoclaved medium was used in culture tubes as slants. Liquid medium prepared similarly without agar was used to grow fungal mycelia for elicitor preparation.

Bacteria: Bacterial culture was maintained on agar slants with solid medium containing proteose peptone $\left(10 \mathrm{~g} \mathrm{~L}^{-1}\right)$, yeast extract $\left(5 \mathrm{~g} \mathrm{~L}^{-1}\right)$, beef extract $\left(10 \mathrm{~g} \mathrm{~L}^{-1}\right)$, dextrose $(20$ $\left.\mathrm{g} \mathrm{L}^{-1}\right)$, tween-80 $\left(1 \mathrm{~g} \mathrm{~L}^{-1}\right)$, ammonium citrate $\left(2 \mathrm{~g} \mathrm{~L}^{-1}\right)$, sodium acetate $\left(5 \mathrm{~g} \mathrm{~L}^{-1}\right)$, Magnesium sulphate $\left(0.1 \mathrm{~g} \mathrm{~L}^{-1}\right)$, Manganese sulphate $\left(0.05 \mathrm{~g} \mathrm{~L} \mathrm{~L}^{-1}\right)$ and di-potassium phosphate $\left(2 \mathrm{~g} \mathrm{~L}^{-1}\right)$. The $\mathrm{pH}$ was adjusted to 6.5 before addition of agar. Liquid medium was prepared identically to solid medium but without agar.

\section{Elicitor preparation}

The cultures maintained on agar slants, were transferred to $100 \mathrm{ml}$ of the respective liquid medium in 250-ml flasks and incubated at room temperature. The bacterial and yeast cultures were kept on a shaker (90 rpm), while the fungal cultures were allowed to stand without shaking. The cultures were harvested after they reached their stationary phase (i.e., 3 weeks for fungal cultures, $72 \mathrm{hrs}$ for yeast 
Elicitation of peroxidase activity in genetically transformed root cultures of Beta vulgaris $\mathrm{L}$.

Table 1. Elicitation of peroxidase activity $\left(\times 10^{6} \mathrm{U} \mathrm{L}^{-1}\right)$ using dry cell powders (DCPs) and culture filtrates (CFs) of fungi. Each value is the mean \pm standard error of six replicates.

\begin{tabular}{|c|c|c|c|c|c|c|c|c|}
\hline \multicolumn{2}{|c|}{ Dry cell powders (DCPs) } & \multicolumn{3}{|c|}{ Time of elicitor addition (day) } & \multirow{2}{*}{$\begin{array}{c}\text { Culture filtrates (CFs) } \\
\text { Treatment } \\
\%(\mathrm{v} / \mathrm{v})\end{array}$} & \multicolumn{3}{|c|}{ Time of elicitor addition (day) } \\
\hline & $\begin{array}{c}\text { Treatment } \\
\%(w / v)\end{array}$ & 15 & 18 & 20 & & 15 & 18 & 20 \\
\hline Control* $^{*}$ & & $2.75 \pm 0.05$ & $2.85 \pm 0.03$ & $2.80 \pm 0.04$ & Control $^{*}$ & $2.75 \pm 0.05$ & $2.85 \pm 0.03$ & $2.80 \pm 0.04$ \\
\hline \multirow{3}{*}{ parasiticus } & 0.10 & $4.15 \pm 0.12^{\mathrm{ef}}$ & $2.30 \pm 0.21^{\mathrm{e}}$ & $7.40 \pm 0.32^{b}$ & 1.0 & $5.20 \pm 0.21^{\mathrm{bc}}$ & $6.58 \pm 0.23^{c}$ & $3.77 \pm 0.16^{\mathrm{e}}$ \\
\hline & 0.25 & $3.80 \pm 0.23^{\text {ef }}$ & ${ }^{f} 2.55 \pm 0.12^{e}$ & $5.15 \pm 0.21^{\mathrm{de}}$ & 2.5 & $5.63 \pm 0.22^{b}$ & $6.93 \pm 0.32^{\mathrm{bc}}$ & $6.63 \pm 0.24^{\mathrm{cb}}$ \\
\hline & 0.50 & $5.95 \pm 0.22^{\text {cd }}$ & $6.55 \pm 0.41^{a}$ & $3.95 \pm 0.10^{\text {ef }}$ & 5.0 & $6.58 \pm 0.34^{\mathrm{a}}$ & $8.47 \pm 0.21^{\mathrm{a}}$ & $5.88 \pm 0.35^{c}$ \\
\hline \multirow{3}{*}{ niger } & 0.10 & $2.40 \pm 0.23^{\text {ef }}$ & $6.53 \pm 0.38^{a}$ & $2.53 \pm 0.12^{g}$ & 1.0 & $3.74 \pm 0.12^{\mathrm{cd}}$ & $6.02 \pm 0.05^{\mathrm{cd}}$ & $6.46 \pm 0.31^{\mathrm{cb}}$ \\
\hline & 0.25 & $7.51 \pm 0.10^{b}$ & $4.90 \pm 0.15^{\mathrm{bc}}$ & $5.55 \pm 0.31^{d}$ & 2.5 & $4.20 \pm 0.24^{\mathrm{cd}}$ & $5.20 \pm 0.21^{d e}$ & $6.93 \pm 0.21^{b}$ \\
\hline & 0.50 & $7.05 \pm 0.23^{\mathrm{bc}}$ & $4.79 \pm 0.12^{\mathrm{bc}}$ & $6.60 \pm 0.23^{c}$ & 5.0 & $6.08 \pm 0.32^{\mathrm{ab}}$ & $3.21 \pm 0.34^{\mathrm{fg}}$ & $7.50 \pm 0.20^{\mathrm{ab}}$ \\
\hline \multirow{3}{*}{ P. notatum } & 0.10 & $7.66 \pm 0.41^{\mathrm{b}}$ & $6.25 \pm 0.31^{\mathrm{ab}}$ & $8.45 \pm 0.41^{a}$ & 1.0 & $3.30 \pm 0.10^{\mathrm{de}}$ & $7.76 \pm 0.42^{\mathrm{ab}}$ & $5.96 \pm 0.32^{c}$ \\
\hline & 0.25 & $4.20 \pm 0.21^{\mathrm{ef}}$ & $3.40 \pm 0.23^{d}$ & $5.67 \pm 0.21^{d}$ & 2.5 & $4.48 \pm 0.15^{c}$ & $6.00 \pm 0.12^{\mathrm{cd}}$ & $8.02 \pm 0.25^{a}$ \\
\hline & 0.50 & $4.15 \pm 0.10^{\text {ef }}$ & ${ }^{f} 2.18 \pm 0.05^{e f}$ & $5.13 \pm 0.23^{\mathrm{de}}$ & 5.0 & $4.29 \pm 0.23^{c}$ & $5.99 \pm 0.11^{\mathrm{cd}}$ & $8.19 \pm 0.21^{\mathrm{a}}$ \\
\hline \multirow{3}{*}{ R. oligosporus } & 0.10 & $5.55 \pm 0.23^{\mathrm{cd}}$ & $1.90 \pm 0.25^{\mathrm{ef}}$ & $4.30 \pm 0.12^{\mathrm{e}}$ & 1.0 & $3.63 \pm 0.14^{d}$ & $4.84 \pm 0.15^{\mathrm{de}}$ & $8.19 \pm 0.27^{a}$ \\
\hline & 0.25 & $8.51 \pm 0.22^{a}$ & $3.40 \pm 0.03^{d}$ & $5.55 \pm 0.34^{d}$ & 2.5 & $5.60 \pm 0.51^{b}$ & $6.65 \pm 0.10^{c}$ & $6.52 \pm 0.11^{\mathrm{cb}}$ \\
\hline & 0.50 & $1.70 \pm 0.04^{g}$ & $2.35 \pm 0.08^{e}$ & $2.25 \pm 0.23^{g}$ & 5.0 & $4.11 \pm 0.21^{c d}$ & $4.17 \pm 0.09^{\mathrm{ef}}$ & $7.28 \pm 0.05^{\mathrm{ab}}$ \\
\hline
\end{tabular}

*Simultaneous controls for each treatment were used. However, control data of all the experiments were averaged to minimise error. Mean \pm SE followed by the same letter within the column are not statistically significant at $p \leq 0.05$ according to ANOVA.

culture and $48 \mathrm{hrs}$ for bacterial culture). The flasks were autoclaved and the fungal mycelial mat which floated at the surface of the medium was carefully removed and washed multiple times with sterile distilled water and allowed to dry in a hot air oven at $40^{\circ} \mathrm{C}$, crushed into powder using mortar and pestle and used as DCP. The remaining medium i.e., $\mathrm{CF}$ was centrifuged to remove suspended particles, filtered through Whatman No. 1 filter paper and the clear solution obtained was stored at $4^{\circ} \mathrm{C}$ for further use. Similarly, for yeast and bacterial cultures, the culture broth was centrifuged at high speed for $1 \mathrm{~h}$ and the cell sediment was air-dried and used as DCP the respective spent medium for use as $\mathrm{CF}$ was stored at $4^{\circ} \mathrm{C}$.

\section{Purified biotic elicitors}

The compounds and their concentrations were selected based on earlier studies (Suresh et al. 2004). Thus Mej was used at $20,40,60,80,100 \mu \mathrm{M}$ whereas GSH was used at different levels such as $0.5 \mathrm{mM}, 1.0 \mathrm{mM}, 1.5,2,4,6,8,10$ $\mathrm{mM}$.

\section{Abiotic elicitors}

Different abiotic elicitors used included metal ions such as calcium and magnesium, and an hormonal elicitor thidiazuron (TDZ). Metal ions were used at various levels such as 2, 4 and 8 folds of their respective concentrations in the normal MS medium. TDZ was used at $0.25 \mathrm{ppm}, 0.50$ ppm and $1.0 \mathrm{ppm}$ in MS liquid medium.

\section{Addition of elicitors}

Fifty milligrams of hairy roots had been grown in $15 \mathrm{ml}$ Murashige and Skoog's (1962) liquid medium (MS) in an Erlenmeyer flask, incubated in dark on a rotary shaker with $90 \mathrm{rpm}$ at $25 \pm 1^{\circ} \mathrm{C}$ for 15,18 and 20 days. The mycelial / cell powders prepared as above were weighed and added to MS basal and the $\mathrm{pH}$ was adjusted to 5.8 before autoclaving at $15 \mathrm{psi}$ for $20 \mathrm{~min}$. The culture filtrates of respective fungi, bacteria and yeast were also used $(\mathrm{v} / \mathrm{v})$ similarly to prepare the elicitation medium. Thus prepared elicitation medium was used to elicitate hairy root cultures at three 
Table 2. Influence of Yeast (C. versatalis) and Bacterial (L. helveticus) elicitors on peroxidase activity $\left(\times 10^{6} U L^{-1}\right)$. Each value is the mean \pm SE of six replicates.

\begin{tabular}{|c|c|c|c|c|c|c|c|c|}
\hline \multicolumn{2}{|c|}{ Dry cell powders (DCPs) } & \multicolumn{3}{|c|}{ Time of elicitor addition (day) } & \multirow{2}{*}{\begin{tabular}{|c|}
$\begin{array}{c}\text { Culture filtrates } \\
\text { (CFs) }\end{array}$ \\
$\begin{array}{c}\text { Treatment } \\
\%(\mathrm{v} / \mathrm{v})\end{array}$ \\
\end{tabular}} & \multicolumn{3}{|c|}{ Time of elicitor addition (day) } \\
\hline & $\begin{array}{l}\text { Treatment } \\
\%(w / v)\end{array}$ & 15 & 18 & 20 & & 15 & 18 & 20 \\
\hline Control $^{*}$ & & $2.75 \pm 0.05$ & $2.85 \pm 0.03$ & $2.80 \pm 0.04$ & Control* $^{*}$ & $2.75 \pm 0.05$ & $2.85 \pm 0.03$ & $2.80 \pm 0.04$ \\
\hline \multirow[t]{3}{*}{ C. versatalis } & 0.10 & $9.68 \pm 0.33^{\mathrm{a}}$ & $9.63 \pm 0.28^{a}$ & $5.43 \pm 0.12^{\mathrm{a}}$ & 1.0 & $1.25 \pm 0.11^{\mathrm{a}}$ & $0.72 \pm 0.33^{\mathrm{ab}}$ & $1.18 \pm 0.15^{\mathrm{a}}$ \\
\hline & 0.25 & $8.76 \pm 0.16^{\mathrm{ab}}$ & $8.25 \pm 0.15^{b c}$ & $5.03 \pm 0.11^{\mathrm{ab}}$ & 2.5 & $0.77 \pm 0.32^{\mathrm{ab}}$ & $1.41 \pm 0.12^{a}$ & $0.49 \pm 0.20^{\mathrm{ab}}$ \\
\hline & 0.50 & $7.32 \pm 0.33^{\mathrm{c}}$ & $7.83 \pm 0.22^{b c}$ & ${ }^{c} 4.92 \pm 0.03^{\mathrm{ab}}$ & 5.0 & $0.36 \pm 0.04^{\mathrm{ab}}$ & $0.58 \pm 0.25^{\mathrm{ab}}$ & $0.62 \pm 0.34^{\mathrm{ab}}$ \\
\hline \multirow[t]{3}{*}{ L. helveticus } & 0.10 & $6.45 \pm 0.12^{d}$ & $8.07 \pm 0.21^{b c}$ & ${ }^{c} 3.56 \pm 0.32^{c}$ & 1.0 & $0.53 \pm 0.02^{\mathrm{ab}}$ & $0.76 \pm 0.05^{\mathrm{ab}}$ & $0.67 \pm 0.11^{a b}$ \\
\hline & 0.25 & $5.35 \pm 0.24^{\mathrm{e}}$ & $7.40 \pm 0.18^{c}$ & $3.51 \pm 0.41^{\mathrm{c}}$ & 2.5 & $1.19 \pm 0.14^{\mathrm{a}}$ & $0.85 \pm 0.11^{a b}$ & $0.40 \pm 0.01^{\mathrm{ab}}$ \\
\hline & 0.50 & $4.35 \pm 0.02^{f}$ & $6.95 \pm 0.41^{\mathrm{cd}}$ & $3.47 \pm 0.19^{c}$ & 5.0 & $0.68 \pm 0.32^{\mathrm{ab}}$ & $0.20 \pm 0.34^{b}$ & $0.56 \pm 0.30^{\mathrm{ab}}$ \\
\hline
\end{tabular}

*Though simultaneous controls for all the treatments were used, control data of all the experiments were averaged to minimise error. Mean \pm SE followed by the same letter within the column are not statistically significant at $p \leq 0.05$ according to ANOVA.

different time periods such as $15^{\text {th }}, 18^{\text {th }}$ and $20^{\text {th }}$ day of the total culture period of 25 days by replacing the spent medium at respective culture stages. Control cultures received fresh MS medium without elicitor addition. The enzyme production was estimated by extracting on the $25^{\text {th }}$ day of the culture period. Abiotic elicitors such as calcium, magnesium and TDZ were weighed and added to MS medium and the $\mathrm{pH}$ adjusted before autoclaving as mentioned above. The other two abiotic elicitors GSH and Mej were used by preparing stock solution and were directly added to autoclaved medium after filter sterilization using $0.22 \mu$ Sartorius ${ }^{\circledR}$ filters. Culture conditions for further monitoring of growth and POD activity were as explained earlier.

\section{Combined effect of biotic elicitors and GSH}

The possible combined effects of the best complex microbial elicitor and purified biotic elicitor GSH were studied by using the best fungal elicitors such as $0.25 \%$ DCP of $R$. oligosporus, $5 \%$ CF of $A$. parasiticus and $0.1 \%$ DCP of yeast $C$. versatilis with different concentrations of GSH such as $0.5-2 \mathrm{mM}$. The elicitor medium was prepared as explained earlier for the respective fungal and yeast elicitors and filter sterilized ( $0.22 \mu$ Sartorius) GSH was added at various concentrations and used for elicitating hairy roots grown for 15 days. The enzyme was extracted on $25^{\text {th }}$ day, assayed, quantified and expressed as productivity in terms of $\mathrm{UL}^{-1}$ medium used.

\section{Extraction of POD, assay and estimation of protein}

POD was extracted by homogenizing $50 \mathrm{mg}$ fresh tissue of hairy roots, in $1 \mathrm{ml}$ of sodium phosphate buffer $(\mathrm{pH} \mathrm{6})$. After homogenization the homogenate was centrifuged at $5000 \mathrm{xg}$ twice and the supernatant was assayed for POD activity by following the method of Wititsuwannakul et al. (1997). Briefly, $1 \mathrm{ml}$ assay mixture was prepared which consisted of $100 \mu \mathrm{l}$ of $0.08 \mathrm{M} \mathrm{H}_{2} \mathrm{O}_{2}, 100 \mu \mathrm{l}$ of $0.008 \mathrm{M}$ ortho-di-anisidine hydrochloride obtained from a stock solution of $0.25 \%(\mathrm{w} / \mathrm{v})(7.88 \mathrm{mM} \sim 0.08 \mathrm{M}), 10 \mu \mathrm{l}$ of enzyme extract and $790 \mu 1$ of respective buffer. The change in $\mathrm{OD}$ at $460 \mathrm{~nm}$ per minute $\left(\mathrm{dA} \min ^{-1}\right)$ at $27^{\circ} \mathrm{C}$ was recorded using kinetic program in UV- visible spectrophotometer (Shimadzu UV-160A). The results were expressed as units per litre medium i.e., activities in biomass + medium for one litre of medium input (productivity). Activity was quantified on the basis of standard curve of horseradish POD enzyme obtained from ICN-biochemicals. One unit of enzyme activity refers to rate of change of 1 OD per minute. To quantify the extracellular POD in the medium, the spent medium was centrifuged twice at $6000 \mathrm{xg}$ at $4^{\circ} \mathrm{C}$ to remove cell debris and the supernatant was assayed for enzyme activity. Estimation of total protein content in the crude extracts was done by adding reducing agents such as $\mathrm{NaCl}$ and cysteine to the extract. This was followed by precipitation of the total protein using TCA, re-dissolving in $2 \mathrm{~N} \mathrm{NaOH}$ to determine total protein concentration, following the method of Lowry et al. (1951). The protein content data was used to 
check the specific activity of POD when required. The relationship between POD and total protein during the course of culture has been presented in our previous study (Thimmaraju et al. 2005).

\section{Statistical analyses}

The data presented is an average of at least six replicates from two individual experiments. The data was further analyzed for variance using Microsoft Excel 2000 version, followed by a Student $t$ test (Sokal and Rolf, 1995).

\section{RESULTS AND DISCUSSION}

Elicitors are compounds of biological or non-biological origin, which upon contact with plant cells, trigger defenserelated compounds through over-expression of relevant enzymes (Singh, 1999; Gómez-Vásquez et al. 2004). It is well established that these defence-related responses are activated through a signal transduction pathway that
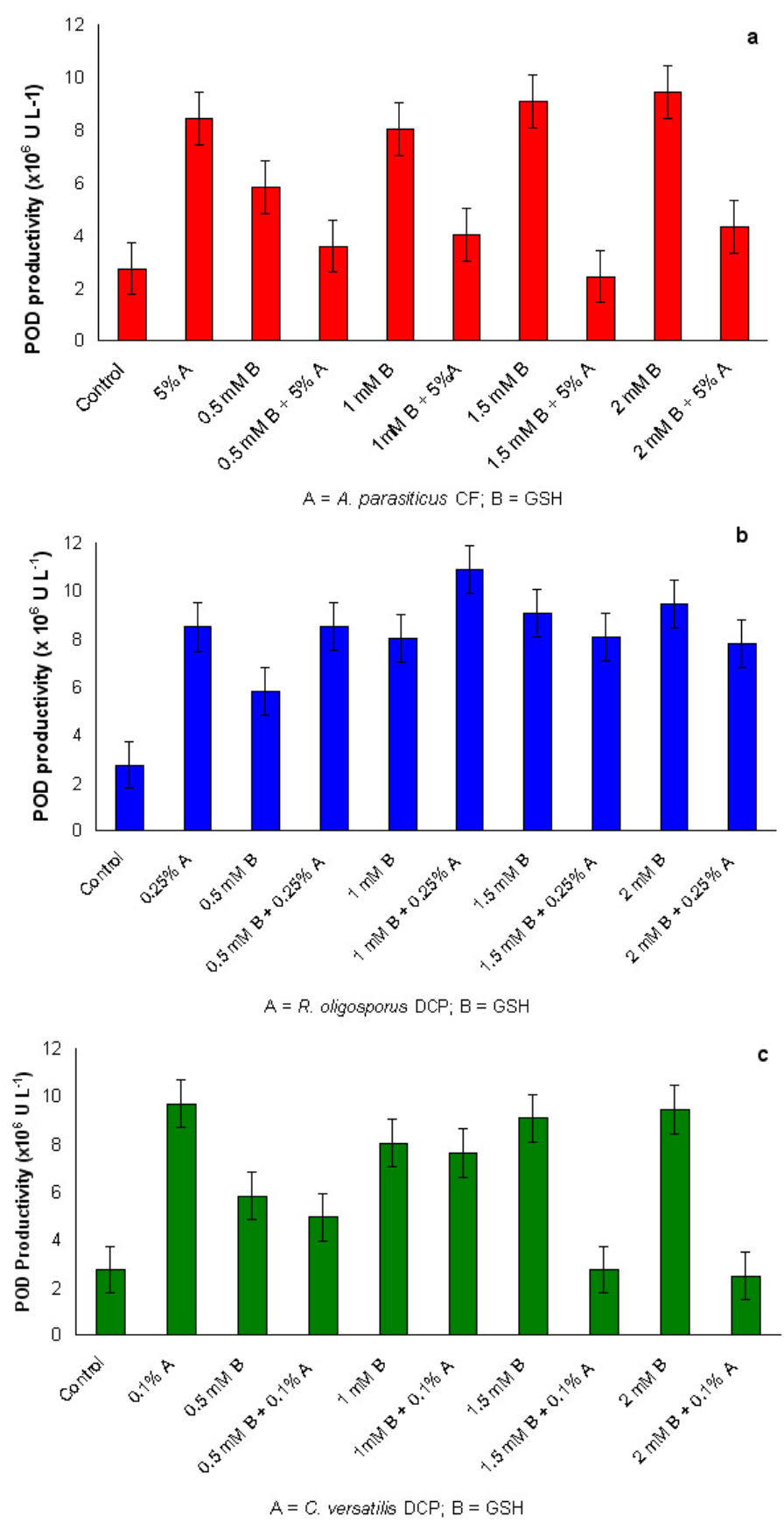

Figure 1. Combined effects of elicitors.

(a) Peroxidase activity under the influence of glutathione $+\mathrm{CF}$ of $A$. parasiticus.

(b) Peroxidase activity under the influence of glutathione $+0.25 \%$ DCP of $R$. oligosporus.

(c) Peroxidase activity under the influence of glutathione $+0.1 \%$ DCPof $C$. versatalis. 
includes the recognition of elicitors by receptors located in the plasma-membrane, activation of ion fluxes across the membrane, induction of down-stream functions such as oxidative bursts (free radical formation) and formation of secondary messengers (Radman et al. 2003). Due to such high specificities of actions, failure of one elicitor does not necessarily mean that the metabolic pathway cannot be triggered indicating that a large number of elicitors have to be screened for accomplishing effective elicitation process. Conversely, a combination of inappropriate medium and elicitor, as well as unsuitable concentration of the latter can result in ineffective elicitation. For example, the phenylpropanoid (PP) pathway was not induced in any cultures of Vanilla planifolia by yeast extract, whereas the same elicitor was used by the same group of workers to induce phytoalexin in cultures of Glycine max. The PP pathway could however be triggered in $V$. planifolia by using chitosan as an elicitor (Gómez-Vázquez et al. 2004). Thus, successful application of elicitation requires extensive screening. Most of the earlier studies on elicitation of peroxidase enzyme involved in vivo plants in response to pathogenic organisms (Gomez-Vazquez et al. 2004; Perera and Jones, 2004). However, a few studies focused on the elicitation of POD in in vitro cultures using mostly one elicitor (Agostini et al. 1997; Flocco et al. 1998; Flocco and Giulietti, 2003; Xu et al. 2004) but so far no report exists on elicitation of POD from red beet hairy roots.

The results of the present study show (Table 1) that among the fungal elicitors, the majority of the treatments resulted in elicited levels of enzyme activities. The highest were those with DCPs of both $R$. oligosporus (added on $15^{\text {th }}$ day) and $P$. notatum (added on $20^{\text {th }}$ day) causing enhancements to the tune of 3-fold higher activity than the control. High levels $(5 \% \mathrm{v} / \mathrm{v})$ of culture filtrates of $A$. parasiticus and $P$. notatum $(2.5-5 \% \mathrm{v} / \mathrm{v})$ enhanced POD activity by nearly $3-$ fold. However, a low level of $(1 \%)$ culture filtrate of $R$ oligosporus was needed to cause similar levels of elicitation in a short period of 5 days.

The dry cell powders of yeast $C$. versatilis elicited the activity of POD up to 3.5-fold at very low concentration whereas the culture filtrates suppressed the turn over of enzyme activity (Table 2). Dry cell powder of $L$. helveticus elicited nearly 3 -fold when added on $15^{\text {th }}$ day, only at a low concentration of $0.10 \%$. Higher levels of yeast DCP were however inhibitory in a dose-dependent manner (Table 2). Similar to most of the earlier studies where fungal elicitors have been found feasible for elicitation, the results of present work also indicated that the biotic elicitors caused elicitation of POD. An important observation made from the present screening study was that the concentration and time of elicitor contact were very critical factors for efficient elicitation of POD as observed in the elicitation of secondary metabolites in other species (Singh, 1999). CF of C. versatilis (Table 2) and L. helviticus did not cause elicitation of POD at any of the levels used. Instead there was a concentration-dependent suppression of POD, therefore, the results of the present study could indicate that the receptors for elicitation in this case are responsive for high molecular weight cell wall polysaccharides that are present in DCP rather than in CF.

In horseradish hairy roots, significant enhancement of POD $(100 \%)$ occurred upon treatment of cultures with certain metal ions such as $\mathrm{AgNO}_{3}, \mathrm{CuSO}_{4}$ and fungal extracts such as Verticillium sp., Monodyctis cataneae and Aspergillus niger (Uozumi et al. 1992). Heterotrophic hairy root cultures of Ipomea aquatica were found to produce twice the amount of POD when they were made photoautotrophic, in which the requirement of POD for scavenging the released toxic oxidants, the peroxides, has been suggested (Uozumi et al. 1992). Nevertheless, the hairy roots used in the present study have been observed to show much higher levels of POD activities than what is reported so far under non-elicited conditions. Additional enhancement of POD activity was accomplished upon elicitation. The fact that the enzyme POD has several isoforms that are active at several physiological $\mathrm{pH}$ (Thimmaraju et al. 2005) indicates that each isoform might respond to elicitation differently for a particular elicitor.

Among the pure compounds (Table 3), GSH used at 5 concentrations at three different treatment time caused highest elicitation at lowest concentration of $2 \mathrm{mM}$ producing about 3.44-fold higher POD activity than the respective control where a contact period of 10 days was required. Mej in the present study, when used at 5 different concentrations caused suppression of POD activity by about 50\% when compared to control cultures (Table 3 ). The role of jasmonate and its methyl derivative in activating the expression of genes (Farmer and Ryan, 1990; Gundlach et al. 1992; Ellard-Ivey and Douglas, 1996; Menke et al. 1999; Van der Fits and Memelink, 2000) and the accumulation of phytoalexins and secondary metabolites has been confirmed in various plant systems (Gundlach et al. 1992; Aerts et al. 1994; Gantet et al. 1998; Lee-Parsons et al. 2004). These studies provide evidence that jasmonates along with $\mathrm{Ca}^{2+}$ are critical in mediating the defence response to pathogens and elicitors. However, the reduction/suppression of POD activity after Mej treatment in the present study could be due to the possibility of release of moderate to high levels of $\mathrm{H}_{2} \mathrm{O}_{2}$ or oxidative burst. However, this needs confirmation regarding the endogenous levels of $\mathrm{H}_{2} \mathrm{O}_{2}$ and/or $\mathrm{O}^{-}$. While the effect of magnesium was based on concentration, calcium caused a fluctuating effect. In the present study, production of highest POD activity of 3.01-fold higher over the control cultures (Table 3) was observed with the highest concentration (6 fold) of Magnesium in the shortest contact period of 5 days. Calcium also caused elicitation in a similar way, in a concentration dependent manner. Elicitation effects of these metal ions could be attributed to their reported roles as both nutrient (Agostini et al. 1997) and secondary signaling molecules in the responses that follow elicitation (Pitta-Alvarez et al. 2000; Radman et al. 2003; Van Huystee et al. 2004). Even in case of defence 
Elicitation of peroxidase activity in genetically transformed root cultures of Beta vulgaris $\mathrm{L}$.

Table 3. Elicitation of POD activity (x $10^{6} \mathrm{U} \mathrm{L}^{-1}$ ) purified biotic (GSH and Mej) and abiotic elicitors (Mg, Ca and TDZ). The values are mean \pm SE of six replicates.

\begin{tabular}{|c|c|c|c|c|}
\hline \multirow{2}{*}{\multicolumn{2}{|c|}{ Treatment }} & \multicolumn{3}{|c|}{ Time of elicitor addition (day) } \\
\hline & & \multirow{2}{*}{$\begin{array}{c}15 \\
2.75 \pm 0.05\end{array}$} & \multirow{2}{*}{$\frac{18}{2.85 \pm 0.03}$} & \multirow{2}{*}{$\begin{array}{c}20 \\
2.80 \pm 0.04\end{array}$} \\
\hline Control* $^{*}$ & & & & \\
\hline Glutathione (GSH) & $\begin{array}{c}2 \mathrm{mM} \\
4 \mathrm{mM} \\
6 \mathrm{mM} \\
8 \mathrm{mM} \\
10 \mathrm{mM}\end{array}$ & $\begin{array}{c}9.46 \pm 0.32^{\mathrm{a}} \\
4.81 \pm 0.23^{\mathrm{ef}} \\
4.44 \pm 0.22^{\mathrm{f}} \\
4.22 \pm 0.18^{\mathrm{gf}} \\
4.73 \pm 0.09^{\mathrm{ef}}\end{array}$ & $\begin{array}{l}5.65 \pm 0.41^{\mathrm{b}} \\
6.08 \pm 0.07^{\mathrm{ab}} \\
5.63 \pm 0.21^{\mathrm{b}} \\
6.59 \pm 0.38^{\mathrm{a}} \\
6.29 \pm 0.12^{\mathrm{a}}\end{array}$ & $\begin{array}{l}5.73 \pm 0.32^{\mathrm{cd}} \\
5.84 \pm 0.21^{\mathrm{cd}} \\
7.18 \pm 0.10^{\mathrm{cb}} \\
6.24 \pm 0.41^{\mathrm{cd}} \\
6.63 \pm 0.12^{\mathrm{c}}\end{array}$ \\
\hline Methyl jasmonate (Mej) & $\begin{array}{c}20 \mu \mathrm{M} \\
40 \mu \mathrm{M} \\
60 \mu \mathrm{M} \\
80 \mu \mathrm{M} \\
100 \mu \mathrm{m}\end{array}$ & $\begin{array}{l}1.39 \pm 0.10^{\mathrm{i}} \\
1.83 \pm 0.41^{\mathrm{hh}} \\
1.59 \pm 0.05^{\mathrm{i}} \\
1.15 \pm 0.23^{\mathrm{ji}} \\
1.17 \pm 0.08^{\mathrm{ji}}\end{array}$ & $\begin{array}{c}2.33 \pm 0.38^{\text {ef }} \\
1.66 \pm 0.15^{f} \\
1.64 \pm 0.03^{f} \\
1.71 \pm 0.21^{\text {ef }} \\
1.68 \pm 0.08^{\text {ef }}\end{array}$ & $\begin{array}{l}1.38 \pm 0.23^{h} \\
1.52 \pm 0.12^{h} \\
1.43 \pm 0.12^{h} \\
0.11 \pm 0.05^{\text {ih }} \\
1.39 \pm 0.06^{h}\end{array}$ \\
\hline Magnesium (Mg) & $\begin{array}{l}2 \text { fold } \\
4 \text { fold } \\
6 \text { fold }\end{array}$ & $\begin{array}{c}6.10 \pm 0.23^{\mathrm{ed}} \\
6.20 \pm 0.10^{\mathrm{ed}} \\
7.40 \pm 0.23^{\mathrm{c}}\end{array}$ & $\begin{array}{l}5.01 \pm 0.31^{\mathrm{cb}} \\
5.04 \pm 0.05^{\mathrm{cb}} \\
5.51 \pm 0.21^{\mathrm{b}}\end{array}$ & $\begin{array}{l}6.05 \pm 0.12^{\mathrm{cd}} \\
7.20 \pm 0.31^{\mathrm{cb}} \\
8.49 \pm 0.23^{\mathrm{a}}\end{array}$ \\
\hline Calcium (Ca) & $\begin{array}{l}2 \text { fold } \\
4 \text { fold } \\
6 \text { fold }\end{array}$ & $\begin{array}{l}7.15 \pm 0.41^{\mathrm{cd}} \\
6.67 \pm 0.21^{\mathrm{d}} \\
5.87 \pm 0.10^{\mathrm{ed}}\end{array}$ & $\begin{array}{l}6.38 \pm 0.05^{\mathrm{a}} \\
6.39 \pm 0.12^{\mathrm{a}} \\
5.26 \pm 0.08^{\mathrm{cb}}\end{array}$ & $\begin{array}{l}6.18 \pm 0.41^{\mathrm{cd}} \\
7.87 \pm 0.21^{\mathrm{ab}} \\
7.68 \pm 0.23^{\mathrm{b}}\end{array}$ \\
\hline Thidiazuron (TDZ) & $\begin{array}{l}0.25 \mathrm{ppm} \\
0.50 \mathrm{ppm} \\
1.00 \mathrm{ppm}\end{array}$ & $\begin{array}{l}5.54 \pm 0.23^{\mathrm{e}} \\
5.54 \pm 0.22^{\mathrm{e}} \\
5.04 \pm 0.04^{\mathrm{ef}}\end{array}$ & $\begin{array}{l}3.75 \pm 0.23^{\mathrm{cd}} \\
3.61 \pm 0.10^{\mathrm{d}} \\
6.85 \pm 0.23^{\mathrm{a}}\end{array}$ & $\begin{array}{l}6.74 \pm 0.12^{c} \\
3.53 \pm 0.34^{f} \\
3.63 \pm 0.23^{f}\end{array}$ \\
\hline
\end{tabular}

*Though simultaneous controls for all the treatments were used, control data of all the experiments were averaged to minimize error. Mean \pm SE followed by the same letter within the column are not statistically significant at $p \leq 0.05$ according to ANOVA.

responses against pathogen attacks that result in the production of phytoalexins and secondary metabolites, there are clear evidences establishing the fact that $\mathrm{Ca}^{+2}$ and Mej are critical in mediating such defence responses (Van Huystee et al. 2004). For eliciting POD activity, abiotic elicitors, particularly ions (readily available as salts) are more practical and cost-effective unlike biotic elicitors that need several processing steps. It is well-known that most of the defence responses by a plant cell to microbial attacks are mediated either through alterations in membrane properties followed by signal transduction during which calcium has been a proven participant molecule triggering a cascade of biochemical reactions within the cell, including efflux and influx of other ions (Graham and Graham, 1999; Lee-Parsons and Ertürk, 2005). Apart from these signaling functions, $\mathrm{Ca}^{2+}$ in particular, is a component of POD where the activity of POD was based on the presence of calcium or any other ion of equal ionic radius (Schuller et al. 1996). In the present study, the presence of adequate levels of minerals in control medium rule out the chances of loss of $\mathrm{Ca}^{2+}$ from POD molecules and hence no the loss of enzyme activity can be expected. Similar to ions, Mej and GSH have also been known for their implications in signaling functions mediating a cascade of defence responses
(Graham and Graham, 1999; Vranová et al. 2002; LeeParsons and Ertürk, 2005). Mej in particular has been reported to elicit secondary metabolites (where POD is implicated) in suspension cultures of various plant species (Graham and Graham, 1999). Although Mej failed to elicit POD in the present study, another secondary metabolite of the pheylpropanoid pathway, the betalain, was enhanced (Suresh et al. 2004). The suppression of POD activity observed in the Mej-treated cultures was mainly due to suppression of biomass itself. However, the suppression mediated by endogenous $\mathrm{H}_{2} \mathrm{O}_{2}$ and/or $\mathrm{O}^{-}$(Radman et al. 2003) cannot be ruled out.

TDZ caused the highest elicitation of POD activity at 1 ppm whereas a low level of $0.25 \mathrm{ppm}$ also caused a similar elicitation when added at a later stage i.e., on the $20^{\text {th }}$ day. Conclusively, the present study has established that among the abiotic elicitors only GSH has significantly enhanced POD activity and more so in the presence of DCP of $R$. oligosporus (as explained below).

\section{Combined effect of GSH and crude biotic elicitors}

Among various combinations of the three elicitors such as GSH, CF of A. parasiticus, DCPs of $R$. oligosporus, and $C$. 
versatilis, only the combination of $1 \mathrm{mM} \mathrm{GSH}$ with $0.25 \%$ DCP of $R$. oligosporus caused the highest elicitation of about 4-fold with a total POD activity of $10.9 \times 10^{6} \mathrm{UL}^{-1}$ when compared to the individual components (Figure 1). Other combinations either suppressed or caused very little elicitation of POD activity when compared to the effect of individual components (Figure 1). This again indicates the preference of high molecular weight polysaccharides (DCPs) for the induction of elicitation cascades in red beet hairy roots where concentration appeared to play a very important role.

\section{CONCLUDING REMARKS}

Although many researchers have studied elicitation in various systems and recorded the suppression of biomass in elicitor treatment, no attempt had been made to check the possibility of effectively using an elicitor at the late exponential growth phase. For pigment we observed that the addition of elicitor at late exponential phase could enhance the overall productivity (Savitha et al. 2006). The activity of POD was generally high at the early exponential phase (Thimmaraju et al. 2005) and therefore, maximum elicitation also occurred at treatments on the $15^{\text {th }}$ and $18^{\text {th }}$ days rather than on $20^{\text {th }}$ day. Therefore, by judiciously selecting and timing the addition of an elicitor, there is a possibility of enhancing the production of both POD and betalain in the same process, in which case the process of online recovery of pigment developed earlier by us (Thimmaraju et al. 2004) could further be extended for the online recovery of POD, as proposed by Agostini et al. (1997) for turnip hairy roots.

\section{ACKNOWLEDGMENTS}

Encouragement by Dr. V. Prakash, Director, CFTRI for research activities is gratefully acknowledged.

\section{REFERENCES}

AERTS, Rob J.; GISI, Daniel E.; DE CAROLIS, Emidio; DE LUCA, Vincenzo and BAUMANN, Thomas W. Methyl jasmonate vapor increases the developmentally controlled synthesis of alkaloids in Catharanthus and Cinchona seedlings. The Plant Journal, May 1994, vol. 5, no. 5, p. 635-643.

AGOSTINI, Elizabeth; FORCHETTI, Silvia Milrad de and TIGIER, Horacio A. Production of peroxidases by hairy roots of Brassica napus. Plant Cell, Tissue and Organ Culture, June 1997, vol. 47, no. 2, p. 177-182.

ELLARD-IVEY, M. and DOUGLAS, C.J. Role of jasmonates in the elicitor-and wound-inducible expression of defense genes in parsley and transgenic tobacco. Plant Physiology, September 1996, vol. 112, no. 1, p. 183-192.

FARMER, E.E. and RYAN, C.A. Interplant communication: airborne methyl jasmonate induces synthesis of proteinase inhibitors in plant leaves.
Proceedings of National Academy of Sciences of the United States of America, October 1990, vol. 87, no. 19, p. 77137716.

FLOCCO, Cecilia Gabriela.; ALVAREZ, María Alejandra and GIULIETTI, Ana María. Peroxidase production in vitro by Armoracia lapathifolia (horseradish)-transformed root cultures: Effect of elicitation on level and profile of isoenzymes. Biotechnology and Applied Biochemistry, August 1998, vol. 28, no. 1, p. 33-38.

FLOCCO, Cecilia Gabriela and GIULIETTI, Ana Maria. Effect of chitosan on peroxidase activity and isoenzyme profile in hairy root cultures of Armoracia lapathifolia. Applied Biochemistry and Biotechnology, September 2003, vol. 110, no. 3, p. 175-183.

GANTET, Pascal; IMBAULT, Nadine; THIERSAULT, Martine and DOIREAU, Pierre. Necessity of a functional octadecanoid pathway for indole alkaloid synthesis by Catharanthus roseus cell suspensions cultured in an auxinstarved medium. Plant and Cell Physiology, February 1998, vol. 39 , no. 2, p. 220-225.

GÓMEZ-VÁSQUEZ, Rocío; DAY, Robert; BUSHMANN, Holger; RANDLES, Sophie; BEECHING, John R. and COOPER, Richard M. Phenylpropanoids, phenylalanine ammonia lyase and peroxidases in elicitor-challenged cassava (Manihot esculenta) suspension cells and leaves. Annals of Botany, July 2004, vol. 94, no. 1, p. 87-97.

GRAHAM, T.L. and GRAHAM, M.Y. Role of hypersensitive cell death in conditioning elicitation competency and defense potentiation. Physiology and Molecular Plant Pathology, July 1999, vol. 55, no. 1, p. 1320.

GUNDLACH, H.; MULLER, M.J.; KUTCHAN, T.M. and ZENK, M.H. Jasmonic acid is a signal transducer in elicitor-induced plant cell cultures. Proceedings of National Academy of Sciences of the United States of America, March 1992, vol. 89, no. 6, p. 2389-2393.

LEE-PARSONS, Carolyn W.T.; ERTÜRK, Seda and TENGTRAKOOL, Jennifer. Enhancement of ajmalicine production in Catharanthus roseus cell cultures with methyl jasmonate is dependent on timing and dosage of elicitation. Biotechnology Letters, October 2004, vol. 26, no. 20 , p. $1595-1599$.

LEE-PARSONS, Carolyn W.T. and ERTÜRK, Seda. Ajmalicine production in methyl jasmonate-induced Catharanthus roseus cell cultures depends on $\mathrm{Ca}^{2+}$ level. Plant Cell Reports, December 2005, vol. 24, no. 11, p. 677682.

LOWRY, Oliver H.; ROSENBROUGH, Nira J.; FARR, A. Lewis and RANDALL, Rose J. Protein measurement with the folin phenol reagent. Journal of Biological Chemistry, November 1951, vol. 193, no. 1, p. 265-275. 
MENKE, Frank L.H.; PARCHMANN, Stefanie; MUELLER, Martin J.; KIJNE, Jan W. and MEMELINK, Johan. Involvement of the octadecanoid pathway and protein phosphorylation in fungal elicitor-induced expression of terpenoid indole alkaloid biosynthetic genes in Catharanthus roseus. Plant Physiology, April 1999, vol. 119, no. 4, p. 1289-1296.

MURASHIGE, Toshio and SKOOG, Folke. A revised medium for rapid growth and bio assays with tobacco tissue cultures. Physiologia Plantarum, July 1962, vol. 15, no. 3 , p. 473-497.

PERERA, Modika R. and JONES, Michael G.K. Expression of the peroxidase gene promoter (Shpx6b) from Stylosanthes humilis in transgenic plants during insect attack. Entomología Experimentalis et Applicata, June 2004, vol. 111, no. 3, p. 165-171.

PITTA-ALVAREZ, Sandra I.; SPOLLANSKY, Tatiana C. and GIULIETTI, Ana María. The influence of different biotic and abiotic elicitors on the production and profile of tropane alkaloids in hairy root cultures of Brugmansia candida. Enzyme and Microbial Technology, February 2000, vol. 26, no. 2-4, p. 252-258.

RADMAN, Romeo; SAEZ, Teresa; BUCKE, Christopher and KESHAVARZ, Tajalli. Elicitation of plants and microbial cell systems. Biotechnology and Applied Biochemistry, February 2003, vol. 37, no. 1, p. 91-102.

SAVITHA, B. Cheluvaraj; THIMMARAJU, Rudrappa; BHAGYALAKSHMI, Neelwarne and RAVISHANKAR, Aswathanarayana G. Different biotic and abiotic elicitors influence betalain production in hairy root cultures of Beta vulgaris in shake-flask and bioreactor. Process Biochemistry, January 2006, vol. 41, no. 1, p. 50-60.

SCHULLER, David J.; BAN, Nenad; VAN HUYSTEE, Robert B.; McPHERSON, Alexander and POULOS, Thomas L. The crystal structure of peanut peroxidase. Structure, March 1996, vol. 4, no. 3, p. 311-321.

SINGH, Gurmeet. Elicitation-Manipulating and enhancing secondary metabolite production. In: FU, Tong-Jen; SINGH, Gurmeet and CURTIS, Wayne R. eds. Plant cell and tissue culture for the production of food ingredients. New York, USA, Kluwer Academic, 1999, p. 121-128.

SOKAL, Robert R. and ROHLF, F. James. Biometry: The Principles and Practice of Statistics in Biological Research, $3^{\text {rd }}$ Ed. New York, WH Freeman and Company, 1995. 859 p. ISBN 0-71-671254-7.

SURESH, Bhamidi; THIMMARAJU, Rudrappa; BHAGYALAKSHMI, Neelwarne and RAVISHANKAR, Aswathanarayana G. Polyamine and methyl-jasmonate influenced enhancement of betalain production in hairy root cultures of Beta vulgaris grown in a bubble column reactor and studies on efflux of pigments. Process Biochemistry, October 2004, vol. 39, no. 12, p. 2091-2096.

THIMMARAJU, Rudrappa; BHAGYALAKSHMI, Neelwarne and RAVISHANKAR, Aswathanarayana G. In situ and ex situ adsorption and recovery of betalains from hairy root cultures of Beta vulgaris. Biotechnology Progress, June 2004, vol. 20, no. 3, p. 777-785.

THIMMARAJU, Rudrappa; BHAGYALAKSHMI, Neelwarne; KUMAR, Vinod; VENKATACHALAM, Lakshmanan; SREEDHAR, Reddampalli Venkataramareddy and RAVISHANKAR, Aswathanarayana Gokare. Peroxidase production from genetically transformed root cultures of red beet (Beta vulgaris L.); Electronic Journal of Biotechnology [online]. 15 August 2005, vol. 8, no. 2 [cited 2006]. Available from Internet:

http://www.ejbiotechnology.info/content/vol8/issue2/full/1 2/index.html. ISSN 0717-3458.

THIMMARAJU, Rudrappa; BHAGYALAKSHMI, Neelwarne; NARAYAN, Mandayam Singara and RAVISHANKAR, Aswathanarayana G. Food-grade chemical and biological agents permeabilize red beet hairy roots, assisting the release of betalaines. Biotechnology Progress, August 2003, vol. 19, no. 4, p. 1274-1282.

UOZUMI, Nobuyuki; KATO, Yoshihiro; NAKASHIMADA, Yutaka and KOBAYASHI, Takeshi. Excretion of peroxidase from horseradish hairy root in combination with ion supplementation. Applied Microbiology and Biotechnology, August 1992, vol. 37, no. 5, p. 560-565.

UYAMA, Hiroshi and KOBAYASHI, Shiro. Enzymatic synthesis of polyphenols. Current Organic Chemistry, September 2003, vol. 7, no. 13, p. 1387-1397.

VAN DER FITS, Leslie and MEMELINK, Johan. ORCA3, a jasmonate-responsive transcriptional regulator of plant primary and secondary metabolism. Science, July 2000, vol. 289 , no. 5477 , p. 295-297.

VAN HUYSTEE, Robert B.; ROIG, Manuel G.; SHNYROV, Valery L. and SAKHAROV, Ivan Y. Peroxidase stability related to its calcium and glycans. Phytochemistry Reviews, January 2004, vol. 3, no. 1-2, p. 19-28.

VEITCH, Nigel C. Horseradish peroxidase: a modern view of a classic enzyme. Phytochemistry, February 2004, vol. 65 , no. 3, p. 249-259.

VRANOVÁ, Eva; INZÉ, Dirk and VAN BREUSEGEM, Frank. Signal transduction during oxidative stress. Journal of Experimental Botany, May 2002, vol. 53, no. 372, p. 1227-1236. 
Rudrappa, T. et al.

WITITSUWANNAKUL,

Rapepun;

WITITSUWANNAKUL, Dhirayos; SATTAYSEVANA,

Benjamaz and PASITKUL, Piyaporn. Peroxidase from

Hevea brasiliensis bark: purification and properties.

Phytochemistry, January 1997, vol. 44, no. 2, p. 237-241.

XU, Tiefeng; ZHANG, Lei; SUN, Xiaofen; ZHANG, Hanming and TANG, Kexuan. Production and analysis of organic acids in hairy-root cultures of Isatis indigotica Fort. (Indigo woad) Biotechnology and Applied Biochemistry, February 2004, vol. 39, no. 1, p. 123-128. 